\title{
Investigational Product Certificate of Destruction
}

National Cancer Institute

\section{Source}

National Cancer Institute. Investigational Product Certificate of Destruction. NCI

Thesaurus. Code C115472.

Official records stating that the investig ational product has been destroyed. 